Peran Akuntansi Manajemen Dalam Pengambilan Keputusan

\author{
Enny Wati, SE., M.Si \\ ennywati75@gmail.com
}




\section{Sistem Informasi Akuntansi}

\section{Konsep Dasar Akuntansi Manajemen}

Akuntansi Manajemen Dan Akuntansi

Keuangan

\section{Informasi Akuntansi Manajemen}

Tren Yang Mempengaruhi Akuntansi

Manajemen

Respon Akuntansi Manajemen Terhadap

Kebutuhan Manajemen Akan Informasi Akuntansi 


\section{Sistem Informasi Akuntansi}

Sistem Informasi Akuntansi adalah informasi yang menghasilkan output dengan menggunakan input dan berbagai proses yang diperlukan untuk memenuhi tujuan tertentu manajemen

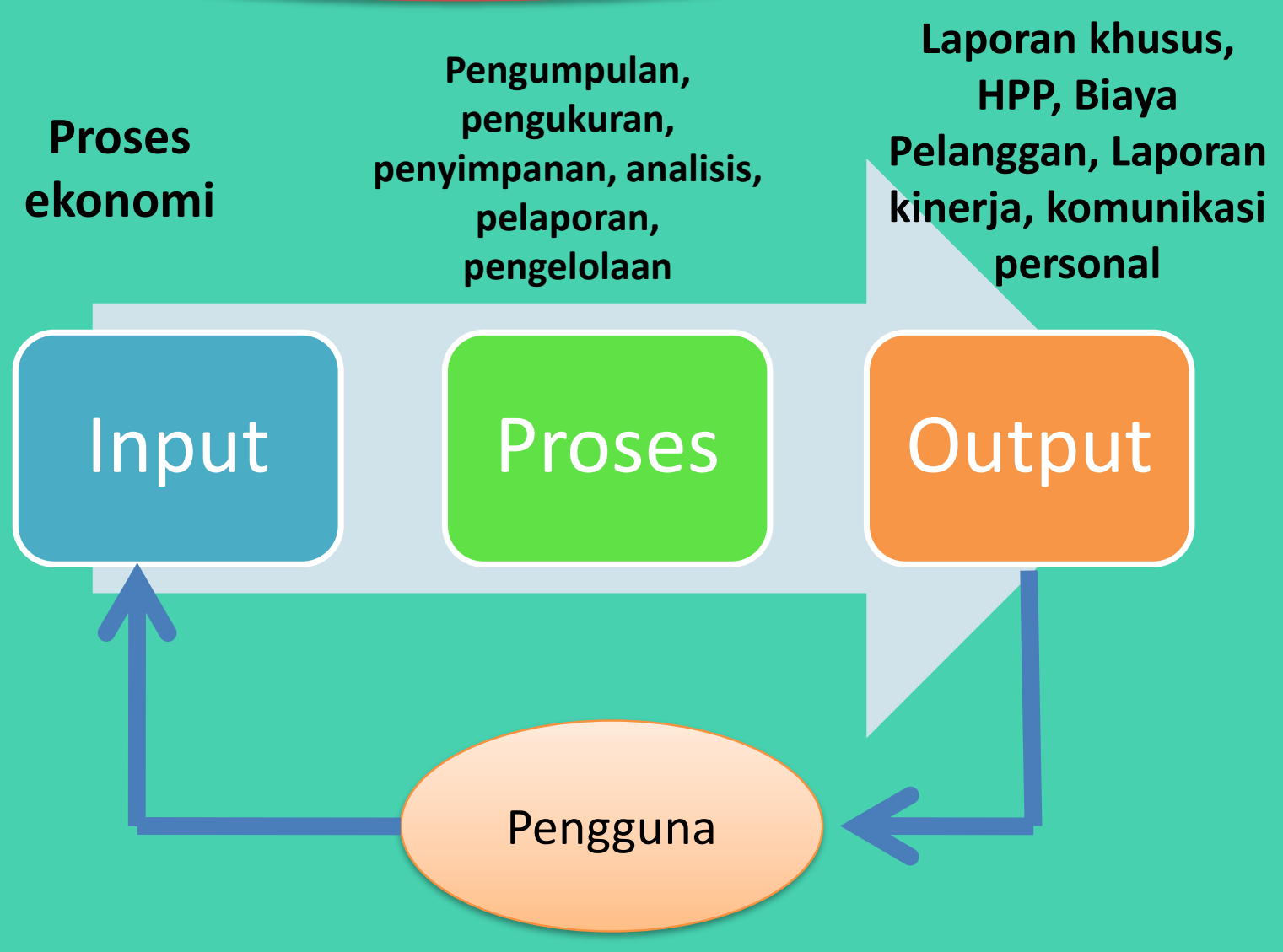




\section{Tujuan Umum Sistem AM}

Perhitungan HP jasa, produk dan tujuan lain

Menyediakan informasi : perencanaan, pengendalian, pengevaaluasian dan perbaikan berkelanjutan

Pengambilan keputusan : identifikasi masalal , solusi dan evaluasi kinerja 


\section{Konsep Dasar Akuntansi Manajemen}

Akuntansi Manajemen adalah penerapan konsep dan metode yang tepat dalam mengolah data ekonomi masa lalu dan membuat proyeksi masa depan suatu usaha untuk membantu manajemen dalam penyusunan rencana/tujuan perusahaan dalam pengambilan keputusan

\section{Konsep}

- Perilaku biaya, hubungan biaya volume dan laba(cost volume and profit), konsep pengambilan keputusan statis dsb

\section{Metode}

- Akuntansi keuangan, akuntansi biaya

\section{Proyeksi}

- Forecasting, regresi linear, biaya tetap, variabel dan semi variabel

AM : bagian dari akuntansi yang berhubungan dengan identifikasi, pengukuran dan komunikasi informasi akuntansi kepada manajemen internal yang bertujuan untuk membantu proses perencanaan, pengendalian dan pengambilan keputusan 


\section{Akuntansi Manajemen Dan Akuntansi Keuangan}

\section{Pengguna}

AM : Internal (manajer, eksekutif dan pekerja)

AK : Eksternal (investor, lembaga pemerintah)

\section{Masukan dan proses}

AM : tidak mengikuti prinsip akuntansi

AK berdasarkan prinsip akuntansi

Jenis Informasi

AM : subyektif (Keuangan dan non keuangan)

AK: objektif dan dapat diverifikasi

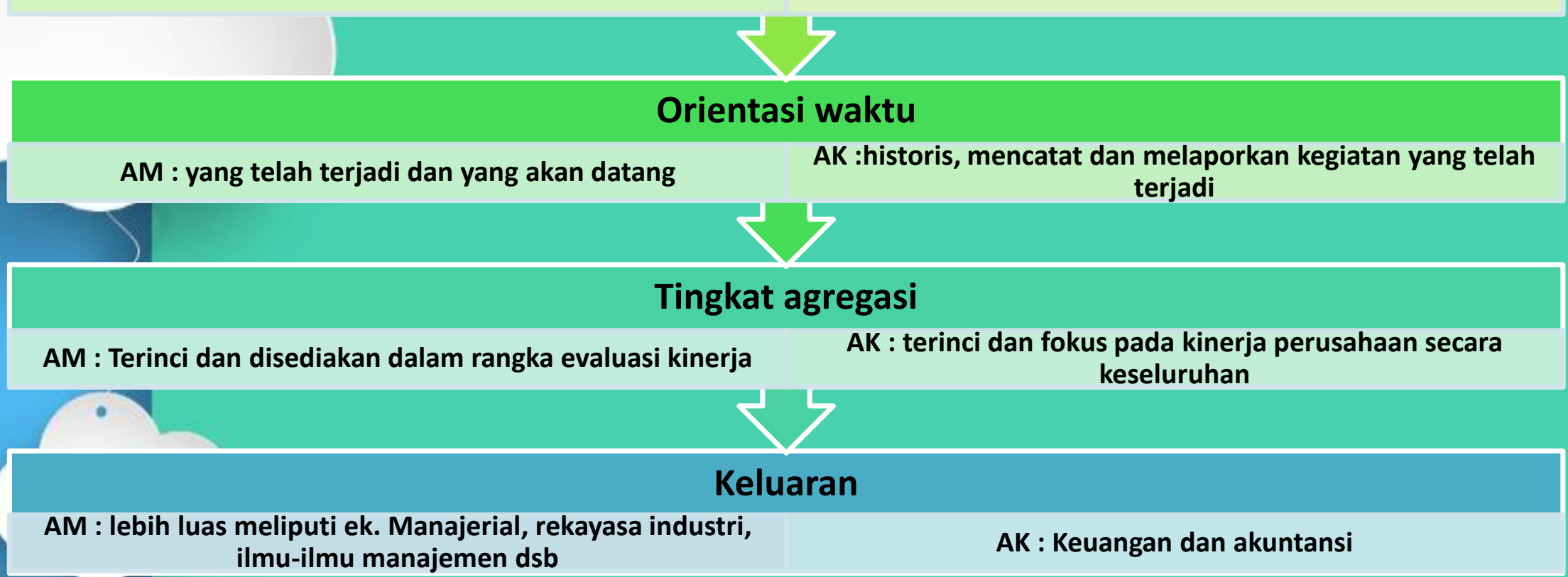




\section{Informasi Akuntansi Manajemen}

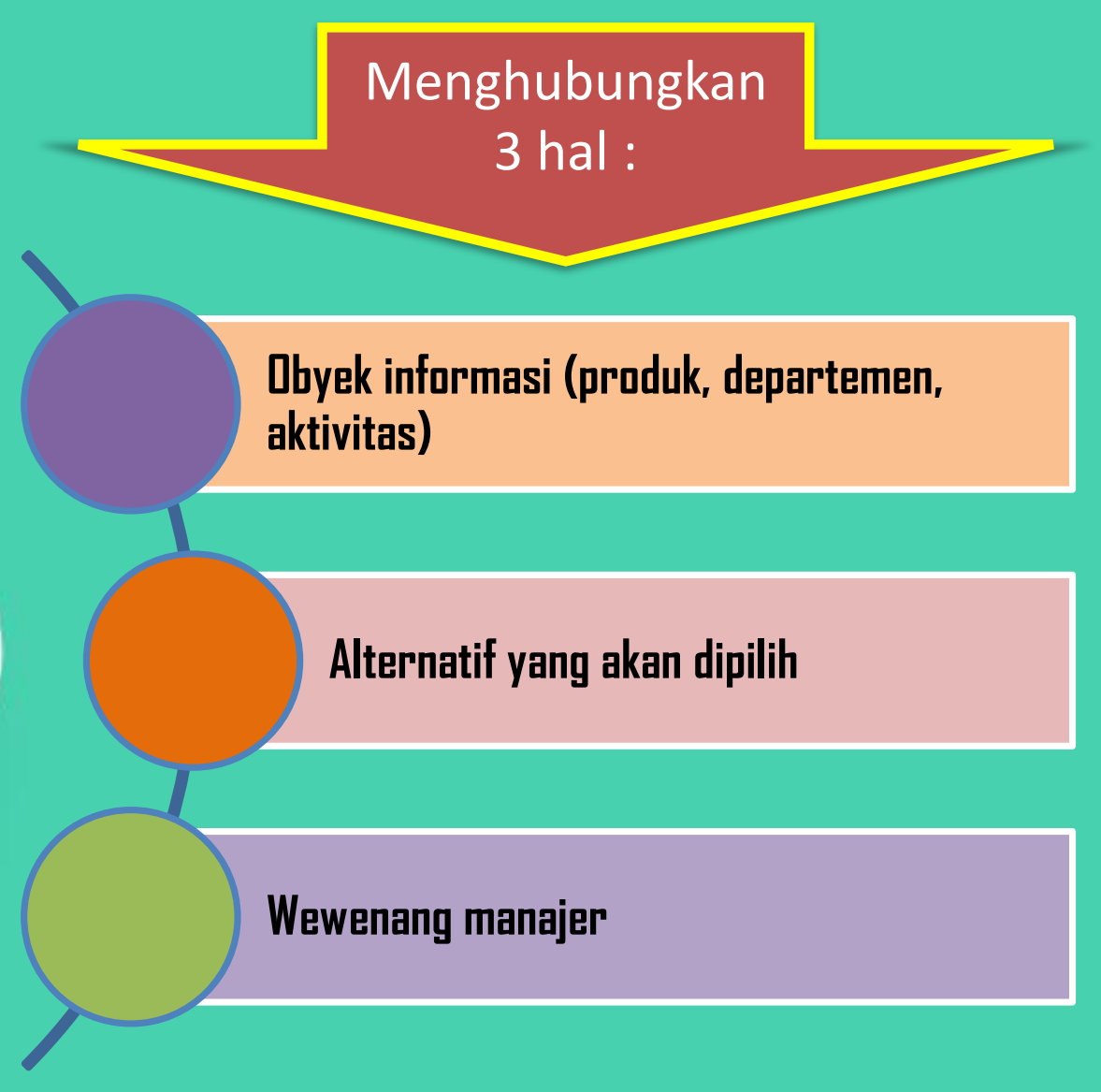




\section{Tipe Informasi Dalam AM}

\section{Informasi akuntansi penuh (full accounting information)}

- Informasi masa lalu bermanfaat : pelaporan informasi keuangan kepada manajemen puncak dan pihak luar perusahaan, analisis kemampuan laba, biayayang telah dikeluarkan, penentuan harga jual

- Informasi masa yang akan datang bermanfaat: penyusunan rencana/program, penentuan harga jual normal, penentuan harga transfer internal, penentuan harga jual yang ditentukan oleh pemerintah

Informasi akuntansi diferensial (diferential accounting information)

- Informasi yang akan datang

- Informasi yang berbeda diantara alternatif yang dihadapi oleh pengambilan keputusan

- Dai meliputi : biaya diferensial, pendapatan diferensial, aktiva diverensial

Informasi akuntansi pertanggungjawaban

- Adalah informasi akuntansi, pendapatan dan biaya yang dihubungkan dengan manajer pertanggungjawaban atas pusat pertanggungjawaban tertentu.

- Meliputi : pusat biaya, pusat pendapatan, pusat investasi,

- Eks : departemen pembelian bertanggung jawab membeli bahan baku atau barang dagangan yang akan dijual kembali 


\section{Tren Yang Mempengaruhi Akuntansi}

\section{Manajemen}

\section{Kemajuan teknologi informasi}

Implementasi JIT manufacturing (metode mengurangi waktu penyimpanan)

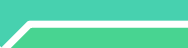

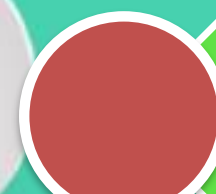

Meningkatnya tuntutan mutu

Meningkatnya diversifikasi dan kompleksitas produk serta semakin pendeknya daur hidup produk

Diperkenalkannya computer integrated manufacturing 
- Melepaskan dominasi ak.keuangan dengan memfokuskan diri pada perekayasaan informasi akuntansi untuk memenuhi kebutuhan manajemen

- Memanfaatkan teknologi komputer untuk merekayasa informasi biaya produk secara lebih cermat

- Mencerminkan konsumsi sumber daya dalam setiap aktivitas untuk menghasilkan produk dengan menerapkan activity based cost system

- Menciptakan target costing untuk memungkinkan manajemen menetapkan market driven strategy dalam memasuki pasar dunia

- Menyediakan informasi product life cycle cost untuk memungkinkan manajemen melakukan strategy cost analisys 


\section{PUSTAKA :}

Salman, K.R. dan Farid, Muh. 2016. Akuntansi Manajemen : Alat Pengukuran dan Pengambilan Keputusan Manajerial. Indeks. Jakarta 


$$
\text { Thank }
$$

